\title{
CONSUMER BEHAVIOUR CHANGES DURING TIMES OF THE COVID-19 PANDEMIC: AN EMPIRICAL STUDY ON SLOVAK CONSUMERS
}

\section{Lenka Veselovská1, Ján Závadský², Lucia Bartkováa}

\footnotetext{
1 University of Matej Bel, Faculty of Economics, Institute of Managerial Systems, Slovakia, ORCID: 0000-0003-1867-2692, lenka.veselovska@umb.sk;

2 University of Matej Bel, Faculty of Economics, Institute of Managerial Systems, Slovakia, ORCID: 0000-0002-4773-3290, jan.zavadsky@umb.sk;

3 University of Matej Bel, Faculty of Economics, Institute of Managerial Systems, Slovakia, ORCID: 0000-0001-5348-2160, lucia.bartkova@umb.sk.
}

\begin{abstract}
The humankind finds itself facing unparalleled situation since the worldwide outbreak of the COVID-19 created significant changes in societies worldwide. This paper aims to assess the initial response of consumers in the Slovak Republic during the early stages of the outbreak and emerged challenges for entrepreneurships. Major pandemics were proven to be a catalyst of changes in societies and economies. The main aim of this research was to examine the impacts of COVID-19 outbreak on consumers' behaviour and draw recommendations for entrepreneurs. A survey was conducted as a method to collect data from consumers creating a representative sample of the population of the Slovak Republic. The rate of consumption has significantly increased when compared before and after the COVID-19 outbreak. The findings show how people of different age, gender and income altered their shopping habits and how the factors influencing their consumers' behaviour changed during this situation. This paper presents one of the first studies on consumer behaviour of Slovak consumers during the COVID-19 pandemic creating a unique image of new reality and emphasizing new trends that will become significant factors of success of entrepreneurs in the near future. It shares practical experiences which can enable organizations to understand consumer behaviour influenced by COVID-19 Pandemic, to investigate novel needs of their customers and to adapt their business to the situation. Some findings such as the increase in need for safety could had been expected, however changes in importance of some factor such as the drastic decrease in brand loyalty or the influence of colleagues, friends and previous experiences with products were surprising. Findings from this study provide useful information for all entrepreneurs that need to understand how their customers have changed and what new demands may arise in the aftermath of this crisis.
\end{abstract}

Keywords: COVID-19, consumer behaviour, rate of consumption, consumer behaviour change index, Slovak Republic.

JEL Classification: M21, M31, I19.

APA Style Citation: Veselovská, L., Závadský, J., \& Bartková, L. (2021). Consumer Behaviour Changes During Times of the COVID-19 Pandemic: An Empirical Study on Slovak Consumers. E\&M Economics and Management, 24(2), 136-152. https://doi.org/10.15240/tul/001/2021-2-009

\section{Introduction}

Humankind finds itself facing unparalleled circumstances since the worldwide outbreak of COVID-19 created significant changes in societies worldwide. Societies were surprised at the rapid spread of the virus and the ensuing global crisis. Due to the worldwide effects of the crises many authors compare it to natural 
disasters (Anderson et al., 2020; Sarkis et al., 2020; De Vito \& Gómez, 2020; Haghani et al., 2020; Haroon \& Rizvi, 2020). The scope of COVID-19 crisis caused significant disruptions in economic, social and health systems, thus creating a challenge for societies. For entrepreneurs, this crisis brought both problems and opportunities. These conditions laid bare their vulnerabilities and critical points. Consumers were forced to adapt their needs and shopping habits to extreme conditions influenced by both implemented and enforced government measures to stop the spread of the virus. As the COVID-19 crisis changes people's lives and wreaked mayhem on the global economy the long-term implications of this pandemic have yet to be determined. The instantaneous effect on consumer behaviour have been severely altered and entrepreneurs must search for efficient and quick coping strategies (Roggeveen \& Sethuraman, 2020; Frechette et al., 2020).

\section{Theoretical Background}

The changes on markets that occurred in 2020 were both drastic and unprecedented. Their consequences have not yet been examined in detail since the situation is still not stable and changes are still occurring. These shifting processes have created a new business reality that needs to be explored and described in order to draw guidelines for entrepreneurs to modify their strategies and apply new methods to fulfil the needs and desires of their customers.

\subsection{Major Events and Their Impacts on Societies in 20th and 21st Century}

The best comparison of a worldwide deadly disease outbreak of this magnitude occurred early in the 20th century. The outbreak of Spanish Influenza took millions of lives globally bring extreme and unparalleled changes to societies and the entrepreneurial environment (Clay et al., 2018; Becker, 1981). The pandemic of 1918-1919 was the most deadly disease of contemporary epoch, taking over 50 million lives in total. Societies were severely impacted and regular life was interrupted in order to deal with that outbreak. The effects on economic processes were enormous creating changes and new developments on businesses influencing market trends for the rest of the century. However, societies and businesses had not yet reached the current state of development that has enabled consumers to freely select desired commonly expected items, a key factor of business decisions for entrepreneurs. Therefore, there is no pertinent precedence to market conditions during the COVID-19 crisis that can be used for comparisons and to rely on for guidance in recent history. However, more localized disruptions with significantly smaller impacts have occurred in the second half of the 20th century. These occurrences were examined and their impacts on consumer behaviour changes were documented. These findings can serve as partial reference for current research with the COVID-19 outbreak on market changes.

Several cases of other major events that impacted societies and the global economy can also be found in the modern history of the world and their effects on entrepreneurs in terms of consumer behaviour were examined in current literature. The 9/11 terrorist attacks in the USA changed the markets significantly and created an atmosphere of fear among societies. This also affected the consumers who radically changed their shopping patterns and attitudes, for example towards airline products. The sharp immediate drop in consumer confidence was immediate and recovery was difficult to sustain (Bechtel, 2003; McMellon \& Long, 2004). A significant incident of this century was the Fukushima Daiichi nuclear power plant disaster. This event incurred significant cost to the Japanese economy and created global implications for entrepreneurs. One example of such effects was the negative response of international consumers to agricultural goods produced in the Fukushima area after the disaster due to fear of health risks (Aruga, 2017; Matsumoto \& Hoang, 2019). Such loss of reputation can be difficult to overcome and even disastrous for some entrepreneurs (Habel et al., 2020).

These findings and their implications have a lot in common in terms of the inevitable necessity to accept change and to adapt the response to emerging customer needs and market opportunities. Moreover, some of such changes tend to remain permanent and even after society returns to a state of normalcy. A fast response of entrepreneurs would be essential not only to satisfy their customers' needs but also to attract potential new customers from yet unexplored markets. Nevertheless, what is absent in the existing 
pool of information provided by literature so far is the actual opinions of customers from the time of the outbreak. This research strives to provide answers to this question by examining the impacts of the COVID-19 outbreak on consumers' economic expectations and their purchasing behaviour.

As of November 2020, the COVID-19 global pandemic caused over 1.3 million deaths around the world out of over 56.7 million confirmed cases. There is no doubt that the 2020 coronavirus disease is a serious health issue for societies affecting all sectors of the economy resulting in an unavoidable crisis and economic recession. Travel limitations, social distancing, self-isolation and other measures implemented by governments to decrease the spread of the virus caused many people to significantly alter their habits and even lifestyles. Some governments were even forced to impose a mandatory lockdowns. Several newly formed phenomenon could be observed right at the initial stages of the outbreak such as panic-buying and stockpiling of food products (Erceg et al., 2020; Jribi et al., 2020). This unprecedented situation caused people to change their consumer behaviour in regards to types and quantities of items they buy, frequency of visiting shops and pre-stocking of supplies at home, because prevention is better than the cure (Aloufi, 2020).

\subsection{Consumer Behaviour}

Consumer behaviour as a basic marketing variable can generally be characterized as human behaviour related to the acquisition, use and disposal of consumer products (Kotler, 1994; Marsden, 2001). Specifically, it is a summary of external manifestations, actions and reactions of an individual. Based on an understanding of consumer behaviour, companies can then create their marketing offer and implement them. Consumer behaviour like any human behaviour is largely individual and mostly hidden. It is influenced by a number of factors that are not directly measurable, so they affect behaviour only in the mind of the consumer. These variables can be measured, but it is not possible to reliably measure exactly how they affect behaviour itself and the consumer's final decision to buy a product (Kirk \& Rifkin, 2020; Hall et al., 2020).

The complexity of consumer behaviour can be characterized by the Black box model.
Consumer behaviour is largely individual and hidden. It is influenced by a number of factors that are not usually directly measurable, so they affect behaviour only in the mind of the consumer. These variables can be measured and expressed, but it is not possible to measure or express exactly how they affect the consumer's own behaviour and his or her final decision to buy the product. That is why it is necessary to consider the customer as a black box we cannot see. But we know the basic variables we need to focus on if we want to understand consumer behaviour as best we can. These are mainly cultural, social, personal and psychological factories influencing the characteristics of the consumer (Soriano et al., 2002). Culture is a fundamental factor influencing a person's wishes and behaviour. It is a set of values, perceptions, preferences and patterns of behaving in certain situations, which a person acquires through the family and institutions during his life. These cultural factors include nationality, religion, education, profession, social class, family, gender, media etc (Huggins et al., 2020; Hiadlovský et al., 2018; Foltys et al., 2015).

Another group of determinants of consumer behaviour is social factors representing influences of other people. Since everyone needs other people for their successful development, a person is characterized by a tendency to associate, to live in a social environment, which is formed by people and their mutual relations, their joint activities, or the products of these activities and relationships (Leung et al., 2020; Povazsayová, 2013). People usually belong to certain groups in which they have given roles and status. The affiliation of people to social groups is determined by the roles and status of individual members of the group. The role represents the position of a person in a group and the activities that are expected. The individual in given this specific role naturally belongs to this task and this subsequently determines the consumer behaviour of a person. Each role creates a status, a position in the group, and thus in society. Reference groups are also important for consumer behaviour since the individual is not a member but wants to become one. These groups significantly influence consumer attitudes and behaviour (Lindridge \& Dibb, 2003).

Consumer behaviour is often influenced by an individual's personal characteristics 
representing a set of different psychological traits that lead to relatively consistent and constant responses to environmental stimuli. Personality is often described by such traits as self-confidence, dominance, independence, pliability, sociability, caution, or adaptability. Personality can be a useful variable, especially when analyzing consumer choice of brands. They often choose brands that have a philosophy with their own self-perception (as they see themselves), although in some cases this coincidence may be based on an idealized perception of the consumer (on how he would like to see himself) or even on how they are perceived by others (as he thinks others see). This may be more pronounced for products consumed in public than for goods consumed in private. The basic personal factors include the age of the buyer, employment and economic circumstances, lifestyle and values (Reed et al., 2012).

Consumer responses to various marketing incentives are significantly influenced by four key psychological processes: motivation, perception, learning and memory. Every person has many needs. A motive is a need that is urgent enough to force a person to act. Motivation is then a state of tension that arose as a result of unmet needs creating the psychological factors influencing consumer behaviour and consumer satisfaction (Zhang et al., 2019; Birtwistle \& Tsim, 2005; Fonseca et al., 2010; Stranjancevic \& Bulatovic, 2015).

In addition to understanding consumer characteristics, it is important for businesses to understand the purchasing decision-making process. The basic model of the purchasing process has five phases (Kotler \& Keller, 2009): problem recognition, information retrieval, evaluation of alternatives, purchasing decision and post-purchase behaviour. The purchasing process begins the moment the buyer finds out that he or she has a problem or need. In order to solve the problem or satisfy the need, the consumer tends to look for information on possible options. The next step in the purchasing process is the evaluation of purchasing alternatives. There is no single process that is used by all consumers, or at least a certain consumer in every purchasing situation, but in general we understand the process of evaluating alternatives as cognitively oriented, so that the consumer makes judgments mostly on a conscious and rational basis. At the stage of evaluating alternatives, the consumer creates inter-brand preferences. In connection with post-purchase behaviour, it is possible to consider the satisfaction, or consumer dissatisfaction, which affects not only further consumer behaviour in the future but also the references it makes about the product and the brand.

The characteristics of the consumer and the purchasing decision process are the internal dimensions of the consumer that are unique to everyone. In addition to these internal factors, consumer behaviour according to the black box model is also influenced by external factors (Kotler \& Keller, 2009): marketing mix of individual companies and other external factories, such as political-legal factors, economic situation in the country, social factors of society, technological and ecological impacts.

These three groups (consumer characteristics, purchasing decision-making process and environmental influences) groups of factors work as an integrated set of stimuli influencing buyer's choices. The importance of individual factors can vary depending on external stimuli. Various authors explored the possible alterations in consumer behaviour due to significant events threatening human lives and the existence of societies (Boustan et al., 2020; Crick \& Crick, 2020; Lal et al., 2020). It was discovered that such changes often endure even after the immediate threat passes, thus creating novel market trends and entrepreneur opportunities.

According to a survey by the research agency 2muse conducted in March 2020 on a representative sample of 311 respondents over the age of 18 (2muse, 2020), 71\% of respondents changed their behaviour when buying food in connection with the occurrence of coronavirus during the first two weeks after the outbreak. During this period, they bought additional food reserves $(60 \%)$, then additional basic household supplies (41\%). The reason for buying more food in stock was that consumers did not have to go out so often. At the time of the research, $8 \%$ of respondents had problems with their financial situation, but up to $49 \%$ expected that their financial situation would worsen in the future. In connection with the financial situation, according to the National Bank of Slovakia, consumers have reduced their consumption (Cesnak et al., 2020). At the same time, shopping has moved more to 
the internet and the use of payment cards has also increased compared to the use of cash (TASR, 2021). Motivated by these evidences, an analyses of consumer behaviour changes developed as a response to COVID-19 outbreak was a natural and necessary step towards understanding the impacts of this crisis on societies' economic activities.

\section{Research Methodology}

Our study provides a detailed assessment of the initial implications of the COVID-19 outbreak for consumers with the focus on changes caused by governmental measures and consumers' own opinions and mind-sets. Both sources of changes in the consumers' purchasing behaviour were evaluated. Therefore, the main aim of this research was to examine the impacts of COVID-19 outbreak on consumers' economic expectations and their purchasing behaviour and draw recommendations for entrepreneurs. An empirical study was performed in order to collect data and examine the opinions of consumers in the Slovak Republic. During spring 2020, Slovakia was among the least affected by the pandemic, however the measures taken by the government were considered to be strict in comparison to other countries. Our questionnaire was disseminated by social media during the early stage of the outbreak in the country between March and April 2020, a time of lock-downs and forced store closing. Consumers were structured primarily by their age in order to ensure the representativeness of sample file of Slovak population. Only customers above the age of 18 were considered. In total 347 complete and viable questionnaires were received. Tab. 1 provides the composition of sample file in comparison to base file which consisted of all citizens above the age of 18 .

The Chi-squared test was used to verify the representativeness of the sample file according to the criterion of consumer's age. The null hypothesis was set with the assumption that the sample is representative. The alternative hypothesis is an assumption of non-representativeness of the sample. From the mathematic point of view, the hypotheses are formulated as:

$$
H_{0}=\mathrm{F}(\mathrm{x})=\mathrm{G}(\mathrm{x}) ; H_{1}=\mathrm{F}(\mathrm{x}) \neq \mathrm{G}(\mathrm{x}) .
$$

Statistic testing in SPSS software is based on the following formula (1):

$$
X^{2}=\sum_{j=1}^{r} \frac{\left(n_{j}-m_{j}\right)^{2}}{m_{j}} \approx X_{(r-1)}^{2}
$$

\section{Tab. 1: Base file and sample file}

\begin{tabular}{l|c|c|c|c}
\multirow{2}{*}{ Age } & \multicolumn{2}{c|}{ Base file } & \multicolumn{2}{c}{ Sample file } \\
\cline { 2 - 5 } & Female & Male & Female & Male \\
\hline $18-25$ & $231,761.00$ & $243,391.00$ & 17 & 19 \\
\hline $26-45$ & $828,505.00$ & $871,910.50$ & 66 & 68 \\
\hline $46-65$ & $736,705.00$ & $705,587.00$ & 59 & 54 \\
\hline Over 66 & $499,118.50$ & $321,201.50$ & 38 & 26 \\
\hline \multirow{2}{*}{ Total } & $2,296,089.50$ & $2,142,090.00$ & 180 & 167 \\
\cline { 2 - 5 } & & $4,438,179.50$ & & 347 \\
\hline 18-25 & $5.22 \%$ & $5.48 \%$ & $4.90 \%$ & $5.48 \%$ \\
\hline $46-45$ & $18.67 \%$ & $19.65 \%$ & $19.02 \%$ & $19.60 \%$ \\
\hline Over 66 & $16.60 \%$ & $15.90 \%$ & $17.00 \%$ & $15.56 \%$ \\
\hline Total & $11.25 \%$ & $7.24 \%$ & $10.95 \%$ & $7.49 \%$ \\
\hline
\end{tabular}


where $\mathrm{X}^{2}$ is Pearson statistics; $\mathrm{r}$ is line; $\mathrm{n}$ is overall frequency in the base file and $m$ is measured frequency.

Consequently, we find the critical value of $\mathrm{X}^{2}$ distribution for $(\mathrm{r}-1)$ degrees of freedom and selected level of significance $\alpha$ from tables of critical values of Chi-squared. The test in this research was performed at a significance level of $95 \%$. If the critical value is lower than the value of tested statistics, null hypothesis is rejected and an alternative hypothesis $H_{1}$ is accepted. The calculated Chi-squared value for this sample was at level 0.844 . This result can be interpreted as the acceptance of the null hypothesis. Therefore, it can be concluded that the sample file is a representative sample of base file.

Other statistic tests were used to analyze the data. Primarily, the Factor analysis was used to analyze collected data and determinate which data could be used to examine which variables and to distinguish the basic composition of analyzed variables in relation to four groups of factors influencing consumer behaviour. An assortment of authors (Crede \& Harms, 2019; Moretti et al., 2019; Veselovská et al., 2020) had previously utilized the Factor analysis to group variables that are remarkably correlated into factors, which can then influence the creation of new complex factors that incorporate all of the information in a more comprehensive way. In addition, Binomial test was utilized to identify the most common variable in the sample file. Spearman's Rank Correlation was used for calculation of dependencies according to formula (2), where the value $n$ is the number of customers and $d$ represents the difference in the ranks:

$$
R_{S}=1-\left(\frac{6 \times \sum d^{2}}{n^{3}-n}\right)
$$

\section{Research Results}

The obvious first occurrence to explore was the possibility of changes in consumer behaviour. All 347 customers stated that they experienced significant transformations. The initial response can be related to perception of current situation. Therefore, the consumers in the sample were asked to provide information on the feelings they had as soon as the first cases of COVID-19 were reported by the media in their country. Tab. 2 presents the results structured by customer characteristics. The results show that males were slightly more optimistic about the initial stages of COVID-19 situation. Only $2.31 \%$ of all customers were very optimistic about the situation and all of them were younger than 26 years. On the other hand, the highest rate of very pessimistic feelings were among consumers between 46-65 years of age since nearly half of them felt this way and more than third of them were mostly pessimistic. The presumption that older the customers are, the more negative feelings they had was tested by calculating the Spearman's RS according to the formula (2). Its value was at 0.529 which indicates medium strong direct relationship between factors.

The initial feelings of customers were further explored by examining them in the context of their income changes that occurred due to the COVID-19 outbreak or measures implemented by government to decrease the spread of the virus. The results are provided in Tab. 3. According to the data more than half

\section{Tab. 2: Initial feelings of customers (spring 2020)}

\begin{tabular}{l|r|r|r|r|r|r}
\multirow{2}{*}{$\begin{array}{l}\text { Initial feelings about the } \\
\text { COVID-19 situation (in \%) }\end{array}$} & \multicolumn{2}{|c|}{ Gender } & \multicolumn{4}{c}{ Age } \\
\cline { 2 - 7 } & Female & Male & $\mathbf{1 8 - 2 5}$ & $\mathbf{2 6 - 4 5}$ & $\mathbf{4 6 - 6 5}$ & over 66 \\
\hline Very optimistic & 1.11 & 3.59 & 22.22 & 0.00 & 0.00 & 0.00 \\
\hline Mostly optimistic & 37.22 & 50.30 & 69.44 & 67.91 & 20.35 & 18.75 \\
\hline Mostly pessimistic & 27.78 & 20.36 & 8.33 & 4.48 & 34.51 & 56.25 \\
\hline Very pessimistic & 33.89 & 25.75 & 0.00 & 27.61 & 45.13 & 25.00 \\
\hline Total & 100.00 & 100.00 & 100.00 & 100.00 & 100.00 & 100.00 \\
\hline
\end{tabular}


Tab. 3: Initial feelings of customers and income changes (spring 2020)

\begin{tabular}{l|c|c|c|c|c}
\multirow{2}{*}{$\begin{array}{c}\text { Initial feelings } \\
\text { (in \% of all } \\
\text { customers) }\end{array}$} & $\begin{array}{c}\text { Significant } \\
\text { increase }\end{array}$ & $\begin{array}{c}\text { Slight } \\
\text { increase }\end{array}$ & No change & $\begin{array}{c}\text { Slight } \\
\text { decrease }\end{array}$ & $\begin{array}{c}\text { Significant } \\
\text { decrease }\end{array}$ \\
\cline { 2 - 6 } Very optimistic & 0.00 & 2.02 & 0.29 & 0.00 & 0.00 \\
\hline Mostly optimistic & 2.59 & 10.37 & 21.04 & 4.32 & 5.19 \\
\hline Mostly pessimistic & 0.58 & 3.75 & 17.29 & 0.00 & 2.59 \\
\hline Very pessimistic & 0.00 & 0.29 & 14.99 & 11.24 & 3.46 \\
\hline
\end{tabular}

of customers experienced no changes in their income $(53.60 \%)$. The incomes decreased for more than a quarter of customers $(26.80 \%)$ and only $19.60 \%$ of customers experienced an increase in their monthly incomes. Interestingly, 2 customers whose incomes significantly increased felt mostly pessimistic about the COVID-19 situation in their country. Therefore, it can be concluded that during COVID-19 crisis the economic factors influencing a purchase were not significantly related to peoples' perception of the situation. The implications for entrepreneurs regarding this finding should emphasize the need of safety that customers may prefer to other incentives for purchase including their own economic situation.

Furthermore, this crisis might have transformed how people distribute their disposable incomes between consumption and savings. Consumers were asked to provide information on what portion of their income they used to buy goods and services. The remaining percentage was assigned as savings. Both the rates of consumption before the outbreak and after the COVID-19 outbreak were explored and compared. Tab. 4 shows the changes according to age of customers. According to the data a rising trend in consumption could be observed after the outbreak. The average consumption rate had been at the level $80.05 \%$, but later increased by $5 \%$ to $85.58 \%$. All customers above the age of 25 years allocated more of their financial resources to consumption and therefore, decreased their savings. The exception being younger customers who did not need to spend more money for buying products since the majority of them lived with their relatives in joint household, decreasing their need for consumption. People over 66 years of age altered their consumption rate only by $0.21 \%$. It is obvious that people distribute their incomes differently during the COVID-19 pandemic. They spend more of their incomes to buy products since they did not trust that their savings would be beneficial for them in a long term. The feelings of uncertainty and anxiety brought on by the pandemic also influenced their preference for satisfying their current instead of keeping up to their long-term plans. However, every crisis inevitably created significant increase in unemployment resulting in loss of income for a portion of population.

Consumer behaviour changes were measured by examining the alterations

\begin{tabular}{l|c|c|c|c}
\multirow{2}{*}{$\begin{array}{c}\text { Rates of consumption } \\
\text { (in \% of monthly income) }\end{array}$} & \multicolumn{4}{|c}{ Age } \\
\cline { 2 - 5 } & $\mathbf{1 8 - 2 5}$ & $\mathbf{2 6 - 4 5}$ & $\mathbf{4 6 - 6 5}$ & Over 66 \\
\hline Before COVID-19 outbreak & 87.31 & 62.48 & 74.52 & 95.90 \\
\hline After COVID-19 outbreak & 86.05 & 74.77 & 85.37 & 96.11 \\
\hline
\end{tabular}


in types and quantities of items they buy, frequency of visiting shops and pre-stocking of supplies at home. Figs. 1, 2, 3 and 4 show the corresponding data according to gender of customers. It was discovered that women were less likely to change the amount of products bought during the early stages of COVID-19 outbreak. Less than a third of them decided to increase the quantities of bought items, whereas $46.71 \%$ of men decided to do so. On the other hand, women tended to change the types of bought items more often than men since $74.44 \%$ of female customers alter the structure of their purchases. Less than $1 \%$ of women increased their frequency of visiting shops during the crisis. The majority of male customers decreased their visits to shops $(49.10 \%)$, however the percentage of female customers who made the same decision was significantly higher $(82.22 \%)$. No women changed their habits in pre-stocking of supplies at home in a form of decrease.

\section{Fig. 1: Changes in quantities of bought items}

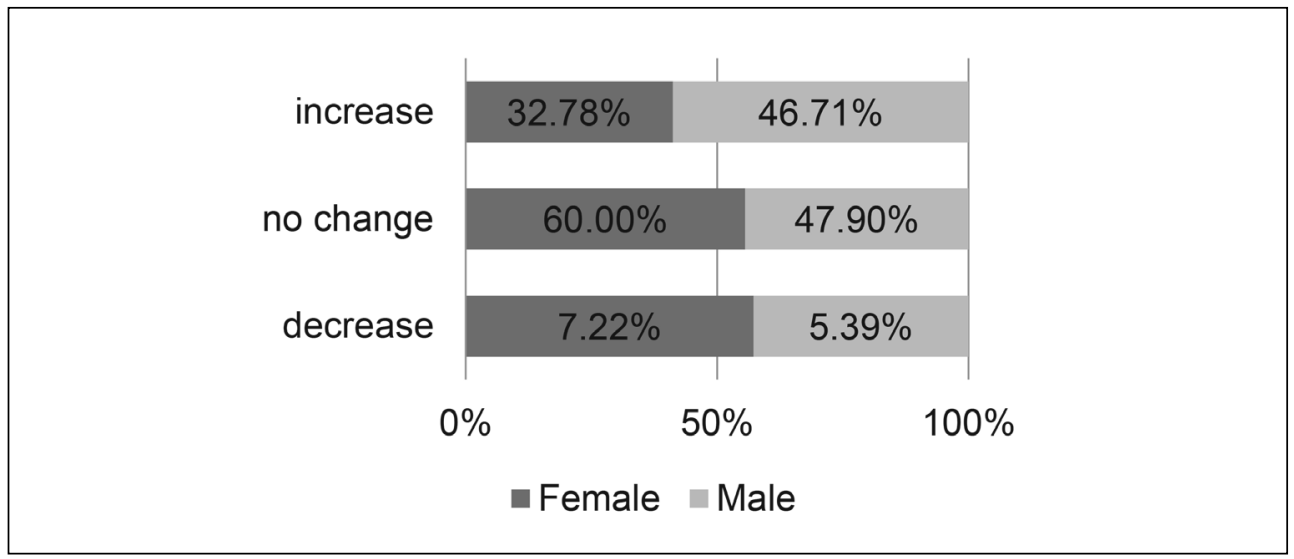

\section{Fig. 2: Changes in types of bought items}

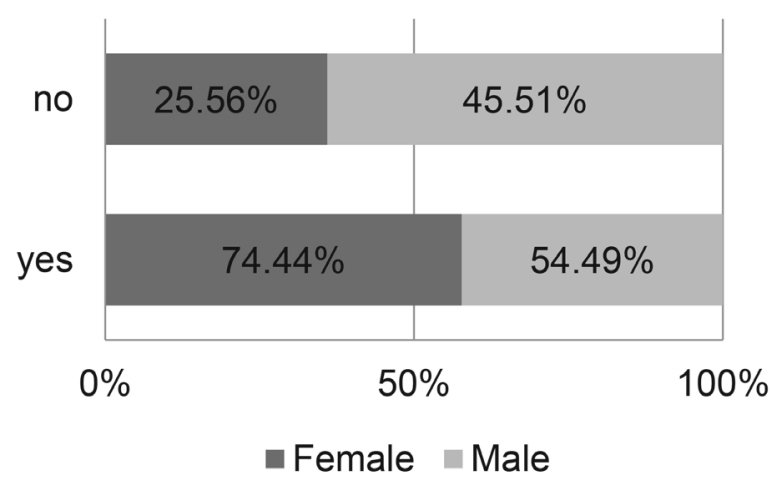




\section{Fig. 3: Changes in frequency of visiting shops}
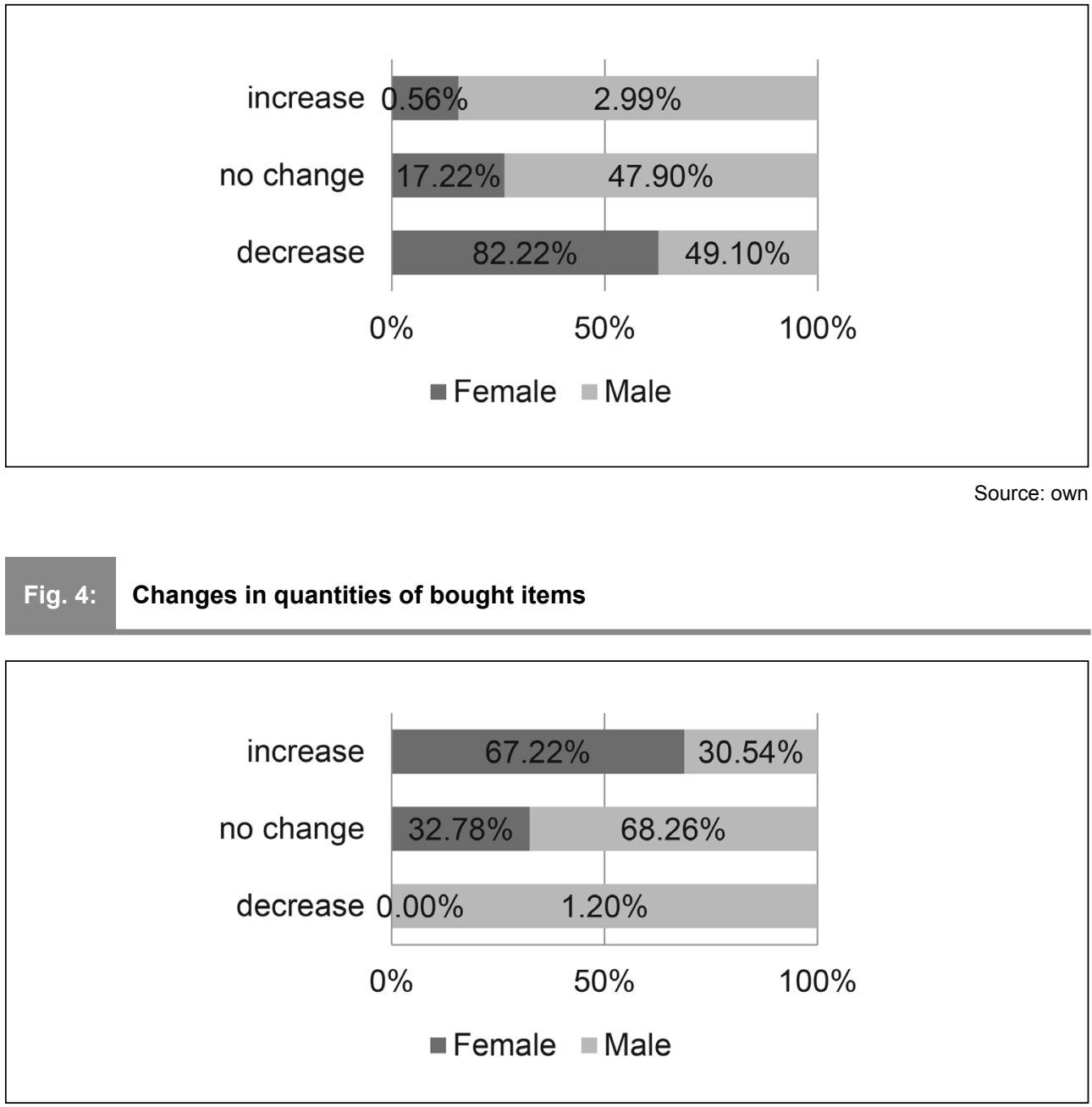

Source: own

In a fact, the majority of them increased their stocks $(67.22 \%)$. It was the opposite for men the majority of whom did not make any changes in their stocking tendencies (68.26\%).

These results indicate that it was the female customers who experienced more significant changes in their customer behaviour during the initial stages of COVID-19 outbreak. In order to explore this presumption a new indicator was created. The consumer behaviour change index $(\mathrm{CBCl})$ was based on the four factors
(Figs. 1-4). If a customer selected the option of no change on any of the factors, it was assigned the value 0 . If a change was stated in a form of increase or decrease, the value 1 was assigned. The maximum cumulated number per customer was 4 . The average values of the index are provided in Tab. 5 for each consumer segment. Consequently, this new indicator was correlated with the factor of gender using the Spearman's Rank Correlation. The value of RS was calculated at the level 0.822 which 
Tab. 5: The consumer behaviour change index

\begin{tabular}{l|c|c|c|c|c|c|c|c}
\hline \multirow{3}{*}{ The CВCI } & \multicolumn{5}{|c|}{ Female } & \multicolumn{4}{c}{ Male } \\
\cline { 2 - 10 } & $\mathbf{1 8 - 2 5}$ & $\mathbf{2 6 - 4 5}$ & $\mathbf{4 6 - 6 5}$ & Over 66 & $\mathbf{1 8 - 2 5}$ & $\mathbf{2 6 - 4 5}$ & $\mathbf{4 6 - 6 5}$ & Over 66 \\
\cline { 2 - 9 } & 3.27 & 2.04 & 1.97 & 2.81 & 1.25 & 2.16 & 2.43 & 2.01 \\
\hline
\end{tabular}

\section{Tab. 6: Comparison of factor groups' importance before and after COVID-19 outbreak}

\begin{tabular}{l|c|c|c|c}
\multicolumn{1}{c|}{ Importance of factors } & $\begin{array}{c}\text { Cultural } \\
\text { factors }\end{array}$ & Social factors & $\begin{array}{c}\text { Personal } \\
\text { factors }\end{array}$ & $\begin{array}{c}\text { Psychological } \\
\text { factors }\end{array}$ \\
\hline Before COVID-19 outbreak & 4.39 & 3.45 & 4.64 & 3.46 \\
\hline After COVID-19 outbreak & 4.36 & 4.98 & 3.83 & 4.12 \\
\hline
\end{tabular}

Source: own

indicates a strong direct relationship between factors. Therefore, it can be concluded that the assumption of female customers making more changes in their customer behaviour than male customers was correct. Only $13.33 \%$ of woman had the value of the customer behaviour change index at the level 0 , whereas the proportion of men was significantly higher $(34.13 \%)$.

In accordance with the data provided in Fig. 1 and 2, the alterations in bought items were further analyzed focusing on food vs. non-food products. It was discovered that the majority of consumers initially significantly increased mainly the quantities of food products they bought. The decrease was observed mainly in products such as clothes and cosmetics that are not essential for peoples' survival. Men who altered the structure of their purchasing focused more on food items since they were unable to eat at restaurants. The discovery that can be considered a positive finding is that only $7.49 \%$ of customers noticed any shortages in stores and even less of them felt affected by them (3.17\%).

Furthermore, new ways of shopping evolved during the COVID-19 pandemic that consumers noticed and utilized. It was discovered that $25.94 \%$ of consumers used the service of delivery of products to peoples' homes. However, $14.69 \%$ of customers used this service for the first time during this crisis. The majority of these customers were elderly, with age over 66 years.

Moreover, influence of 4 groups of factors influencing the consumer behaviour was examined. The importance of cultural, social, personal and psychological factors was evaluated on a scale between 1 to 5 , with 1 representing no importance and 5 representing a significant importance. Tab. 6 shows the comparison of average factors' importance before and after COVID-19 outbreak. It was discovered that social factors were the least influential before the pandemic with psychological factors being the close second. Personal factors were evaluated as the most influential on consumers and their purchasing decisions. However, the strength of influences changed due to COVID-19 outbreak. The importance of personal factors significantly decreased, whereas the influences of social and psychological factors increased. The value of cultural factors has not significantly changed. These results indicate that peoples' core value do not significantly change even during such grave crisis as the COVID-19 pandemic. However, people have become more susceptible to external influences. This provides an opportunity for entrepreneurs to attract more customers through adequate communication tools and messages. This general outlook on the alterations served as a foundation for more detailed analysis according to customers' socioeconomic characteristics (Tab. 7 and 8).

Individual factors within their groups were also evaluated. Out of 36 factors 10 were selected for more detailed analysis. These 10 factors were chosen due to most significant changes in their influences in absolute values 
Tab. 7: Importance of factor groups structured by age and gender of consumers

\begin{tabular}{l|c|c|c|c|c|c|c|c}
\multirow{2}{*}{$\begin{array}{c}\text { Changes in } \\
\text { importance of main } \\
\begin{array}{c}\text { factors after } \\
\text { CoVID-19 outbreak }\end{array}\end{array}$} & $\mathbf{1 8 - 2 5}$ & $\mathbf{2 6 - 4 5}$ & $\mathbf{4 6 - 6 5}$ & Over 66 & $\mathbf{1 8 - 2 5}$ & $\mathbf{2 6 - 4 5}$ & $\mathbf{4 6 - 6 5}$ & Over 66 \\
\cline { 2 - 10 } & 3.04 & 1.75 & 1.21 & 2.45 & 2.41 & 1.44 & 1.11 & 2.06 \\
\hline Family & 3.19 & 2.63 & 1.98 & 2.74 & 3.45 & 2.72 & 1.32 & 2.97 \\
\hline Media & -2.04 & -1.85 & -1.32 & -0.63 & -2.91 & -2.55 & -2.56 & -1.07 \\
\hline Friends & -1.83 & -1.71 & -1.9 & -1.94 & -2.09 & -1.65 & -1.33 & -1.12 \\
\hline Colleagues & -1.96 & -1.85 & -1.73 & -1.05 & -0.54 & -0.71 & -1.6 & -1.95 \\
\hline Previous experiences & 2.56 & 4.11 & 4.78 & 4.92 & 2.61 & 4.86 & 4.89 & 4.94 \\
\hline $\begin{array}{l}\text { Feeling of safety } \\
\text { in shop }\end{array}$ & 2.09 & 0.32 & -0.11 & 1.54 & 1.80 & 0.21 & -0.17 & 2.02 \\
\hline Location of shop & 1.98 & 0.56 & 0.21 & 1.78 & 1.73 & -0.08 & 0.02 & 1.76 \\
\hline Accessibility of shop & -1.28 & -0.95 & 1.54 & 1.61 & -1.35 & -1.14 & 0.78 & 0.81 \\
\hline Advertisements & -2.74 & -3.06 & -1.53 & -3.15 & -0.29 & -1.34 & -1.52 & -2.93 \\
\hline Brand loyalty & & & & & & & & \\
\hline
\end{tabular}

Source: own

before and after COVID-19 outbreak. Tab. 7 shows how the influences of these factors changed between analysed periods. The same scale was used. If the value in Tab. 7 is negative that means the influence of the factors decreased.

According to the data provided in Tab. 7 female consumers were more impacted by the COVID-19 crisis since their factors of influence changed more severely. Serious media such as news and talk shows with professionals become much more influential, especially for younger consumers. On the other hand, the influence of friends and colleagues diminished. The highest increase in influence could be observed for the factors that had virtually no influence at all before the crisis. This newly emerged factor was the feeling of safety in shops. Even the impacts of advertisement shifted, becoming less important for younger consumers and more influential for people above the age of 46 years. Location and accessibility of shops gained significant influence for people above the age of 66 years and consumers younger than 25 years, however almost no alterations in the influence of these factors could be observed for other consumers. Interestingly, even brand loyalty became less important during the COVID-19 crisis suggesting an ability and willingness of customers to adapt their needs and fulfil them with products of different brand. However, men proved to be less likely to change the brands they know and like for products of other brands. These findings create an opportunity for newly emerging entrepreneurs since they may have an easier starting position knowing what the customers currently prefer and what to focus on. The transformation of significance of factors' influence provides recommendations for all entrepreneurs to gain competitive advantage. The key factors that gained importance are family, media and feeling of safety in shop. Therefore, the entrepreneurs' focus should be on creating a safe environment for customers and to transmit this achievement to their existing and potential customers using corresponding marketing tools through media. The main aspect that needs to be addressed is the safety of family that can potentially lead to customers' preference of this entrepreneurs' product or service. Interestingly, the decrease in influence of advertisement campaigns could be an impulse for business to seek other methods to reach their customers, especially new marketing tool that have to yet been previously applied. This information could be a key to success especially for small businesses that could transmit the correct message through more personal contact with customer. The drastic decrease in influence of brand loyalty 


\begin{tabular}{l|c|c|c|c|c}
\multirow{2}{*}{$\begin{array}{c}\text { Changes in } \\
\text { importance of main } \\
\text { factors after } \\
\text { CoVID-19 outbreak }\end{array}$} & $\begin{array}{c}\text { Significant } \\
\text { increase }\end{array}$ & $\begin{array}{c}\text { Slight } \\
\text { increase }\end{array}$ & No change & $\begin{array}{c}\text { Slight } \\
\text { decrease }\end{array}$ & $\begin{array}{c}\text { Significant } \\
\text { decrease }\end{array}$ \\
\hline Family & 1.95 & 1.78 & 0.53 & 2.43 & 2.97 \\
\hline Media & 2.41 & 2.49 & 2.05 & 3.23 & 2.95 \\
\hline Friends & -2.78 & -3.11 & -0.56 & -1.56 & -1.36 \\
\hline Colleagues & -3.12 & -3.03 & -0.21 & -1.35 & -0.81 \\
\hline Previous experiences & -2.49 & -2.17 & -0.47 & -1.06 & -0.91 \\
\hline $\begin{array}{l}\text { Feeling of safety } \\
\text { in shop }\end{array}$ & 3.76 & 4.36 & 3.09 & 4.89 & 4.97 \\
\hline Location of shop & 0.86 & 0.81 & -0.22 & 1.56 & 1.78 \\
\hline Accessibility of shop & -0.14 & 0.97 & 0.28 & 1.34 & 2.55 \\
\hline Advertisements & -2.58 & -0.56 & 0.10 & 1.05 & 1.97 \\
\hline Brand loyalty & -3.81 & -3.04 & -0.06 & -2.27 & -1.16 \\
\hline
\end{tabular}

and slight but significant decrease in influence of previous experiences with products indicates that consumers are ready to try new products. This could also indicate that entrepreneurs should consider launching new products, even during the economic crisis that the pandemic caused. This paradox could signify a risky decision, however, the opinions of consumers indicate that this risk has a very high change of paying off if the process is handled correctly. If the economic situation of enterprise is not ideal, businesses should consider at least modifying their existing products. The stagnations would most likely lead to loss of customers. Consumers are becoming much more hindered by the pandemic, therefore they seek new experiences within the safe environment. On-line marketing has never been more important and campaigns need to incorporate the message of novelty that people currently desire.

Since the consumer behaviour always relates to economic situation of people, the changes in incomes of consumers and their impacts on factors of influence were also evaluated (Tab. 8). Results show that the feeling of safety in shops became more important for all customers regardless of their changed incomes. Another interesting phenomenon that could be observed was the fact that if the influence of a certain factor increased it was mostly because of consumers with decreased incomes and on the other hand if a certain factor became less influential on consumers' behaviour it was due to people with increased incomes. Customers whose incomes changes could not be observed mostly altered their scope of influential factors only slightly with the exception of media and feeling of safety. These challenges have to be addressed by entrepreneurs as soon as possible. Already some adjustments can be observed, especially in advertisement. Recently launched campaigns focused more on how businesses responsibly comply with health and security requirements and how important is the safety of their customers for them. However, other issues such as product requirements and service providing under these circumstances have not yet been properly innovated.

\section{Conclusions}

This research study intended to determine the impacts of COVID-19 outbreak on consumer behaviour and to create a complex image of the changes brought by it during the initial stages of the outbreak. Various authors (McGinnis et al., 2013; Lee \& Schaninger, 2003; Anderson et al., 2020; Hartmann \& Lussier, 2020) noticed that during a crisis people tend to increase their consumption rates and allocate less financial resources to savings, some of them even 
cancel their long-term investments. The results of this research study confirmed that COVID-19 crisis has already caused the same impacts on peoples' tendencies in consumption.

The global health emergency has provoked a worldwide economic crisis. Contemporary practices created as a response to the COVID-19 outbreak such as sheltering in place, isolation and social distancing have significant impacts on the mentality of people and their daily routines (Sarkis et al., 2020; Nguyen et al., 2020; Morrow-Howell et al., 2020). Introduction and a wide-spread use of technology enabled the decrease of face-toface interactions. Public concerns and fear of infection motivated consumers to modify their shopping habits, most notable to decrease their visits to actual shopping areas, even in some cases to prefer shopping online and having items delivered to them. This research study proves that these changes in consumer behaviour were significant, especially for women. Social factors became more influential than they were before the pandemic and its consequent restrictions. Pre-stocking of large amount of food supplies was common, however the majority of consumers did not notice any disruptions or shortages which could either be because of great supply chain adaptability and resilience or due to the ability of consumers to accommodate their needs with different products or combinations of both. This research was carried out on a representative sample of Slovak customers which makes the findings highly relevant for entrepreneurs in this country, but may not have entirely similar implications for entrepreneurs operating in other countries. The Slovak Republic was not as affected by the COVID-19 during the first wave (spring 2020) virus as other countries, though the measures implemented by its government were considered similarly strict and restraining as in other countries. Therefore, the findings from this study are certainly useful for all entrepreneurs that need to understand how their customers have changed and what new demands may arise in the aftermath of this crisis.

Several authors state (Roggeveen \& Sethuraman, 2020; Sarkis et al., 2020; Lemke et al., 2020; Cranfield, 2020; Rubio, 2020) that people are learning to adapt and to modify their motivations for consumptions. Consumers are also likely to become accustomed to new ways of shopping and demand new features from the sellers that had previously not been important to them. As Pantano et al. (2020) discovered that some entrepreneurs reacted rapidly to the emergency. However, what is missing from the research is the customers' response to newly implemented measures in the context of modified needs which this research provides. In the near future, entrepreneurs need to learn to understand and accommodate these newly developed needs, otherwise they may experience a rapid loss of customers who may leave for competition that can provide what they need. The feeling of safety will most likely become a central theme of all shopping experiences. Therefore, those entrepreneurs that can manage to instigate this feeling in their customers will mostly likely survive this crisis without losing customers after the pandemic. In addition, it will be important for entrepreneurs to quickly investigate the novel needs of their customers and take advantage of this opportunity to evolve, as some authors also state (Knight et al., 2020; Shammi et al., 2020; Sharma et al., 2020; Sheth, 2020; He \& Harris, 2020; Wang et al., 2020). Major policy changes necessary to implement will fundamentally alter the business processes and entrepreneurship environment as whole. The adequacy of response of each individual entrepreneur has to be evaluated after a certain period of time in order to provide correct findings regarding the success or failure of individual measures implemented by entrepreneurs. However, only time will tell how these changes will affect the economy and the whole society.

The main limitation of this study lies in its sample size. The sample is representative according to gender of consumers, however it could be argued that its size is rather small to discover all minor changes that occurred in consumer behaviour and describe them in detail. In the future, it would be ideal to conduct this research again on much larger sample with special care provided to the factor of peoples' age. The following research on this topic could not only provide more details on consumer behaviours changes, but also map the changes that occurred after the data was collected in spring 2020.

This research study summarizes the effects of COVID-19 on individual aspects of consumer behaviour. The findings can serve as guidelines for entrepreneurs selling their products during this crisis and even afterwards. A few trends could be observed that formed during the 
COVID-19 pandemic and will define the future development of customer needs. This study can contribute to current research pool on customer behaviour and can serve to further promote research into the socio-economic situations in societies after the pandemic.

Acknowledgment: Supported by the project No. 1/0757/18, "Consumer behaviour in buying goods of daily consumption with an emphasis placed different contents of goods offered on markets of selected EU countries" of the "Research agency of the Ministry of Education, Science, Research and Sport of the Slovak Republic".

\section{References}

2muse. (2020). Spotrebitel'ský pulz počas pandémie koronavírusu [Consumer pulse during a coronavirus pandemic]. Bratislava: 2muse. Retrieved March 17, 2021, from https://www.2muse.sk/sk/blog/spotrebitelskypulz-pocas-pandemie-koronavirusu

Aloufi, M. A. (2020). Effect of clinical decision support systems on quality of care by nurses. International Journal for Quality Research, 14(3), 665-678. https://doi.org/10.24874/ IJQR14.03-01

Anderson, R. M., Heesterbeek, H., Klinkenberg, D., \& Hollingsworth, T. D. (2020). How will country-based mitigation measures influence the course of the COVID-19 epidemic? The Lancet, 395(10228), 931-934. https://doi. org/10.1016/S0140-6736(20)30567-5

Aruga, K. (2017). Consumer responses to food produced near the Fukushima nuclear plant. Environmental Economics and Policy Studies, 19(4), 677-690. https://doi. org/10.1007/s10018-016-0169-y

Bechtel, G. G. (2003). One voice for consumer confidence: Case 9/11. International Journal of Public Opinion Research, 15(3), 325-334. https://doi.org/10.1093/ijpor/15.3.325

Becker, J. J. (1981). 20-million dead + worldwide epidemic - Spanish influenza took its toll. Histoire, 40, 82-83.

Birtwistle, G., \& Tsim, C. (2005). Consumer purchasing behaviour: An investigation of the UK mature women's clothing market. Journal of Consumer Behaviour, 4(6), 453-464. https://doi.org/10.1002/cb.31

Boustan, L. P., Kahn, M. E., Rhode, P. W., \& Yanguas, M. L. (2020). The Effect of
Natural Disasters on Economic Activity in US Counties: A Century of Data. Journal of Urban Economics, 118, 103257. https://doi.org/10.1016/j. jue.2020.103257

Cesnak, M., Cupák, A., Jurašeková Kucserová, J., Jurča, P., Klacso, J., Košútová, A., Moravčík, A., \& Šuster, M. (2020). Vplyv koronakrízy na finančnú situáciu a očakávania zadlžených domácností [The impact of the corona crisis on the financial situation and expectations of indebted households]. Bratislava: National Bank of Slovakia. Retrieved March 17, 2021, from https://www.nbs.sk/img/ Documents/PUBLIK/OP_3-2020-Prieskum_ zadlzenych_domacnosti.pdf

Clay, K., Lewis, J., \& Severnini, E. (2018). Pollution, Infectious Disease and Mortality: Evidence from the 1918 Spanish Influenza Pandemic. Journal of Economic History, 78(4), 1179-1209. https://doi.org/10.1017/ S002205071800058X

Cranfield, J. A. L. (2020). Framing consumer food demand responses in a viral pandemic. Canadian Journal of Agricultural Economics - Revue Canadienne D’Agroéconomie, 68(2), 151-156. https://doi.org/10.1111/cjag.12246

Crede, M., \& Harms, P. (2019). Questionable research practices when using confirmatory factor analysis. Journal of Managerial Psychology, 34(1), 18-30. https://doi.org/10.1108/JMP-06-2018-0272

Crick, J. M., \& Crick, D. (2020). Coopetition and COVID-19: Collaborative business-tobusiness marketing strategies in a pandemic crisis. Industrial Marketing Management, 88, 206-213. https://doi.org/10.1016/j. indmarman.2020.05.016

De Vito, A., \& Gómez, J. P. (2020). Estimating the COVID-19 cash crunch: Global evidence and policy. Journal of Accounting and Public Policy, 39(2), 106741. https://doi. org/10.1016/j.jaccpubpol.2020.106741

Erceg, N., Ružojčić, M., \& Galic, Z. (2020). Misbehaving in the Corona Crisis: The Role of Anxiety and Unfounded Beliefs. Current Psychology: A Journal for Diverse Perspectives on Diverse Psychological Issues. https://doi. org/10.31234/osf.io/cgjw8

Foltys, J., Dębicka-Ozorkiewicz, G., Królczyk, J. B., \& Hiadlovský, V. (2015). Financing craft enterprises associated in the Polish craft association. E\&M Economics and Management, 18(4), 166-183. https://doi. org/10.15240/tul/001/2015-4-012 
Fonseca, F., Pinto, S., \& Brito, C. (2010). Service quality and customer satisfaction in public transports. International Journal for Quality Research, 4(2), 125-130.

Frechette, M., Arnold, M., Kaikati, A., \& Singh, N. (2020). Collaborative consumption, social distance and the extended self. Journal of Consumer Marketing, 37(4), 413-422. https://doi.org/10.1108/JCM-02-2019-3099

Habel, J., Jarotschkin, V., Schmitz, B., Eggert, A., \& Plötner, O. (2020). Industrial buying during the coronavirus pandemic: A cross-cultural study. Industrial Marketing Management, 88, 195-205. https://doi. org/10.1016/j.indmarman.2020.05.015

Haghani, M., Bliemer, M. C. J., Goerlandt, F., \& Li, J. (2020). The scientific literature on Coronaviruses, COVID-19 and its associated safety-related research dimensions: A scientometric analysis and scoping review. Safety Science, 129, 104806. https://doi. org/10.1016/j.ssci.2020.104806

Hall, M. C., Scott, D., \& Gössling, S. (2020). Pandemics, transformations and tourism: be careful what you wish for. Tourism Geographies, 22(3), 577-598. https://doi.org/10.1080/146166 88.2020.1759131

Haroon, O., \& Rizvi, S.A. R. (2020). COVID-19: Media coverage and financial markets behaviour - A sectoral inquiry. Journal of Behavioral and Experimental Finance, 27, 100343. https://doi. org/10.1016/j.jbef.2020.100343

Hartmann, N., \& Lussier, B. (2020). Managing the sales force through the unexpected exogenous COVID-19 crisis. Industrial Marketing Management, 88, 101-111. https://doi.org/10.1016/j.indmarman.2020.05.005

He, H., \& Harris, L. (2020). The impact of Covid-19 pandemic on corporate social responsibility and marketing philosophy. Journal of Business Research, 116, 76-182. https://doi.org/10.1016/j.jbusres.2020.05.030

Hiadlovský, V., Huňady, J., Orviská, M., \& Pisár, P. (2018). Research activities and their relation to economic performance of regions in the European Union. Business Systems Research, 9(1), 44-54. https://doi.org/10.2478/ bsrj-2018-0004

Huggins, K. A., White, D. W., Holloway, B. B., \& Hansen, J. D. (2020). Customer gratitude in relationship marketing strategies: a cross-cultural e-tailing perspective. Journal of Consumer Marketing, 37(4), 445-455. https://doi.org/10.1108/JCM-08-2019-3380
Jribi, S., Ben Ismail, H., Doggui, D., \& Debbabi, H. (2020). COVID-19 virus outbreak lockdown: What impacts on household food wastage? Environment Development and Sustainability, 22(5), 3939-3955. https://doi. org/10.1007/s10668-020-00740-y

Kirk, C. P., \& Rifkin, L. S. (2020). I'll Trade You Diamonds for Toilet Paper: Consumer Reacting, Coping and Adapting Behaviors in the COVID-19 Pandemic. Journal of Business Research, 117, 124-131. https://doi. org/10.1016/j.jbusres.2020.05.028

Knight, L., Meehan, J., Tapinos, E., Menzies, L., \& Pfeiffer, A. (2020). Researching the future of purchasing and supply management: The purpose and potential of scenarios. Journal of Purchasing and Supply Management, 26(3), 100624. https://doi.org/10.1016/j. pursup.2020.100624

Kotler, P. (1994). Reconceptualizing marketing: An interview with Philip Kotler. European Management Journal, 12(4), 353-361. https://doi.org/10.1016/0263-2373(94)90021-3

Kotler, P., \& Keller, K. L. (2009). Marketing Management. Upper Saddle River, NJ: Pearson Prentice Hall.

Lal, P., Kumar A., Kumar, S., Kumari, S., Saikia, P., Dayanandan, A., Adhikari, D., \& Khan, M. L. (2020). The dark cloud with a silver lining: Assessing the impact of the SARS COVID-19 pandemic on the global environment. Science of the Total Environment, 732, 139297. https://doi.org/10.1016/j.scitotenv.2020.139297

Lee, D. H., \& Schaninger, C. M. (2003). Attitudinal and consumption differences among traditional and nontraditional 'childless' couple households. Journal of Consumer Behaviour, 2(3), 248-268. https://doi.org/10.1002/cb.105

Lemke, M. K., Apostolopoulos, Y., \& Sönmez, S. (2020). Syndemic frameworks to understand the effects of COVID-19 on commercial driver stress, health, and safety. Journal of Transport \& Health, 18, 100877. https://doi.org/10.1016/j.jth.2020.100877

Leung, T. Y., Sharma, P., Adithipyangkul, P., \& Hosie, P. (2020). Gender equity and public health outcomes: The COVID-19 experience. Journal of Business Research, 116, 193-198. https://doi.org/10.1016/j.jbusres.2020.05.031

Lindridge, A., \& Dibb, S. (2003). Is 'culture' a justifiable variable for market segmentation? A cross-cultural example. Journal of Consumer Behaviour, 2(3), 269-286. https://doi. org/10.1002/cb.106 
Marsden, D. (2001). Deconstructing consumer behaviour: theory and practice. Journal of Consumer Behaviour, 1(1), 9-21. https://doi.org/10.1002/cb.50

Matsumoto, S., \& Hoang, V. N. (2019). Economic Loss Due to Reputation Damage: A New Model and Its Application to Fukushima Peaches. Journal of Agricultural Economics, 71(2), 581-600. https://doi.org/10.1111/14779552.12366

McGinnis, L. P., Frendle, A. M., \& Gentry, J. W. (2013). The simple man: The consumption behavior of the principled life. Journal of Consumer Behaviour, 12(1), 70-80. https://doi. org/10.1002/cb.1416

McMellon, C. A., \& Long, M. (2004). From patriotic to tasteless: Exploring consumer reactions to 9/11/2001 related advertising. Advances in Consumer Research, 31, 623-629.

Moretti, E. D., Anholon, R., Rampasso, I. S., Silva, D., Santa-Eulalia, L. A., \& Ignacio, P. S. D. (2019). Main difficulties during RFID implementation: an exploratory factor analysis approach. Technology Analysis \& Strategic Management, 31(8), 943-956. https://doi.org/1 $0.1080 / 09537325.2019 .1575351$

Morrow-Howell, N., Galucia, N., \& Swinford, E. (2020). Recovering from the COVID-19 Pandemic: A Focus on Older Adults. Journal of Aging \& Social Policy, 32(4-5), 526-535. https://doi.org/10.1080/08959420.2020.1759758

Nguyen, H. V., Tran, H. X., Huy, L. V., Nguyen, X. N., Thanh, M., \& Nguyen, N. (2020). Online Book Shopping in Vietnam: The Impact of the COVID-19 Pandemic Situation. Publishing Research Quarterly, 36(2), 427-445. https://doi.org/10.1007/s12109-020-09732-2

Pantano, E., Pizzi, G., Scarpi, D., \& Dennis, C. (2020). Competing during a pandemic? Retailers' ups and downs during the COVID-19 outbreak. Journal of Business Research, 116, 209-213. https://doi.org/10.1016/j. jbusres.2020.05.036

Povazsayová, L. (2013). Manažment udržatel'ného rozvoja podniku a integrácia udržatel'ného spoločensky zodpovedného podnikania do vybraných manažérskych funkcií [Management of sustainable business development and integration of sustainable socially responsible business into selected managerial functions]. Výkonnost' podniku, 3(1), 68-75.

Reed, A., Forehand, M. R., Puntoni, S., \& Warlop, L. (2012). Identity-based consumer behavior. International Journal of Research in Marketing, 29(4), 310-321. https://doi. org/10.1016/j.jiresmar.2012.08.002

Roggeveen, A. L., \& Sethuraman, R. (2020). How the COVID-19 Pandemic May Change the World of Retailing. Journal of Retailing, 96(2), 169-171. https://doi.org/10.1016/j. jretai.2020.04.002

Rubio, M. P. G. (2020). Governmentdictated regulations on contracts in view of COVID-19 in Spain. Revista de Derecho Civil, 7(2), 15-46.

Sarkis, J., Cohen, M. J., Dewick, P., \& Schröder, P. (2020). A brave new world: Lessons from the COVID-19 pandemic for transitioning to sustainable supply and production. Resources, Conservation \& Recycling, 159, 104894. https://doi.org/10.1016/j.resconrec. 2020. 104894

Shammi, M., Bodrud-Doza, M., Islam, A. B. M. T., \& Rahman, M. (2020). COVID-19 pandemic, socioeconomic crisis and human stress in resource-limited settings: A case from Bangladesh. Heliyon, 6(5), e04063. https://doi. org/10.1016/j.heliyon.2020.e04063

Sharma, P., Leung, T. Y., Kingshott, R. P. J., Davcik, N. S., \& Cardinali, S. (2020). Managing uncertainty during a global pandemic: An international business perspective. Journal of Business Research, 116, 188-192. https://doi. org/10.1016/j.jbusres.2020.05.026

Sheth, J. (2020). Business of business is more than business: Managing during the Covid crisis. Industrial Marketing Management, 88, 261-264. https://doi.org/10.1016/j. indmarman.2020.05.028

Soriano, M. Y., Foxall, G. R., \& Pearson, G. J. (2002). Emotion and environment: a test of the behavioural perspective model in a Latin American context. Journal of Consumer Behaviour, 2(2), 138-154. https://doi. org/10.1002/cb.96

Stranjancevic, A., \& Bulatovic, I. (2015). Customer satisfaction as an indicator of service quality in tourism and hospitality. International Journal for Quality Research, 9(4), 689-704.

TASR. (2021). Analýza: Pandémia urychluje zmenu nákupného správania Slovákov [Analysis: The pandemic accelerates the change in shopping behavior of Slovaks]. Bratislava: Mafra Slovakia. Retrieved March 17, 2021, from https://finweb.hnonline.sk/ekonomika/2298944analyza-pandemia-urychluje-zmenunakupneho-spravania-slovakov 
Veselovská, L., Závadský, J., \& Závadská, Z. (2020). Mitigating bribery risks to strengthen the corporate social responsibility in accordance with the ISO 37001 . Corporate Social Responsibility and Environmental Management, 27(4), 1972-1988. https://doi. org/10.1002/csr.1909

Wang, Y., Hong, A., Li, X., \& Gao, J. (2020). Marketing innovations during a global crisis:
A study of China firms' response to COVID-19. Journal of Business Research, 116, 214-220. https://doi.org/10.1016/j.jbusres.2020.05.029

Zhang, Y. D., Li, D. J., Zhang, C. B., \& Zhang, H. L. (2019). Quantified or nonquantified: How quantification affects consumers' motivation in goal pursuit. Journal of Consumer Behaviour, 18(2), 120-134. https://doi.org/10.1002/ cb. 1752 